\title{
"Gründerzeit" Ethics in the Dramas by Paul Lindau and Richard Voss
}

\author{
Eldi Grubišić Pulišelić
}

\begin{abstract}
In the "Gründerzeit" period (1870-1890), German dramatists promoted the values created in the spirit of the dominant, particularly conservative patriarchal ideology. They were not encouraging critical self-examination of the co-relation of double standard of morality and social repression; theatre arts contributed to creating certain conservative utopias which can be considered in the light of wider political discourse. Only few writers critically approached the philosophy of life of that period and represented the other side of a culture which to a great part was founded on bourgeois values. Here, two authors will be considered in particular: The first is Paul Lindau (1839-1919) who uncritically pampered to the tastes of the public at that time for which he was rewarded by being extremely popular while the other is Richard Voß (1851-1918), an author who troubled the public with his view of justice and morality. While Paul Lindau in his dramas extolled and idealised the world of "Gründerzeit", Voß showed the psychopathic state caused by the suppression of emotions and libido. The dramas by Paul Lindau (Marion, Maria und Magdalena) and Richard Voß (Alexandra, Eva) can be viewed in the light of the political discourse which was present in theatre of that time; "Gründerzeit" ethics in them show their front and flip side, power and weakness, hypocrisy and social conditioning.
\end{abstract}

\section{Keywords}

Gründerzeit, German drama, ethics, Paul Lindau, Richard Voß

\section{Zusammenfassung}

\section{Die Ethik der Gründerzeit in den Dramen von Paul Lindau und Richard Voß}

Während der Gründerzeit (1870-1890) standen die Werke deutscher Dramatiker im Zeichen einer dominanten und äußerst konservativen patriarchalen Ideologie. Die Theaterkunst trug dazu bei, eine gewisse konservative Utopie zu schaffen, die in einem breiteren politischen Diskurs zu sehen war. Nur wenige Dramatiker setzten sich mit dem Weltbild jener Zeit kritisch auseinander und zeichneten das wahre Gesicht einer Kultur, die in vielen Bereichen auf einer 
bürgerlichen Moral fußte. Die vorliegende Arbeit befasst sich vor allem mit den Werken zweier Autoren: Paul Lindau unterwirft sich kritiklos dem Geschmack des damaligen Publikums, was ihm große Popularität einbringt, Richard Voß dagegen beunruhigt die Zuschauer mit seiner Darstellung von Gerechtigkeit und Moral. Während Paul Lindau in seinen Dramen das Weltbild der Gründerzeit verherrlicht und idealisiert, deutet Voß auf die psychopathologischen Missstände, welche aus der Unterdrückung von Emotionen und Libido resultieren. Die Dramen von Paul Lindau (Marion, Maria und Magdalena) und Richard Voß (Alexandra, Eva) können im Lichte des politischen Diskurses in der Dramatik jener Zeit gesehen werden; die Ethik der Gründerzeit zeigt in den Dramen dieser Autoren ihr Gesicht und Gegengesicht, ihre Stärke und Schwäche, Heuchelei und Gebundenheit an gesellschaftliche Konventionen.

\section{Schlüsselwörter}

Gründerzeit, deutsches Drama, Ethik, Paul Lindau, Richard Voß

\section{1 "Gründerzeit": German Theatre and the Bourgeois Values}

In the "Gründerzeit" ${ }^{1}$ period a new economically and politically powerful social elite was formed which sought ways of self-affirmation in German cultural circles which apart from in architectural painting, in particular manifested itself in theatre arts. On theatre stages towards the end of the 1860's, dramas by German authors started to be performed on social problems. ${ }^{2}$ Despite great popularity at that time, the authors of these dramas are today practically forgotten. ${ }^{3}$ The "Gründerzeit" theatre audience eagerly watched on the stage heroes aspiring towards high ethical standards and most German dramatists of that period satisfied their tastes. The closer their drama performances were to the projection the new social elite had of itself, the more successful they were. The popularity of certain dramas (and their authors) was above all reflected in the large number of theatre performances. Only few writers critically approached the philosophy of life of that period and represented the other side of a culture which to a great part was founded on bourgeois values. German dramatists at that time tended to harmonise and relativise real problems and uncritically promoted the values created in the spirit of the dominant, particularly conservative patriarchal ideology. Male heroes in their dramas based their behaviour on high ethical principles and in the focus of their activity was honour as one of the key concepts of society. As male subjects they were shown as creators, initiators of events and often keepers and/or witnesses to female morality. Strong and moral males were shown in contrast to weak and easily led women who had not managed to resist temptation. After being cast off from society due to violation of moral rules, the heroines of these dramas accepted their death as a prerequisite to

1 The term is used as a historical-literary term (1870-1890). See Kiefer, Sascha: Dramatik der Gründerzeit. Deutsches Drama und Theater 1870-1890. St. Ingbert 1997, pp. 9-10.

2 See Hamann Richard/ Hermand, Jost: Gründerzeit. Epochen deutscher Kultur von 1870 bis zur Gegenwart. München 1974, V/1, pp. 27-33; Kiefer [footnote 1], pp. 11.

3 Mc Innes, Edward: Drama und Theater. In: Mc Innes, Edward/ Plumpe, Gerhard: Bürgerlicher Realismus und Gründerzeit 1848-1890. München 1996, pp. 343-393 (here p. 381). 
resolving the occurring conflict. Instead of encouraging critical self-examination of the co-relation of double standard morals and social repression, theatre arts contributed to creating certain conservative utopias which can be considered in the light of wider political discourse. ${ }^{4}$ German dramatists of that period often used trivial solutions with the aim of embellishing reality and creating illusory harmonies in a idealised society composed of aristocratic and bourgeois elements. ${ }^{5}$ Despite this, issues which these writers polarised on the stage represented something new on the theatre scene. Their female characters conflicted with the code of ethics of the society because they were forced by internal or external factors, but despite this they further leant towards patriarchal values. "Gründerzeit" dramatists took on a moralising attitude so they rewarded and punished their characters according to the life philosophy of the society. ${ }^{6}$ Despite the domination of conservative ethical standards, it is possible with some authors to observe subversive elements, that is, a critical attitude towards the concept of male honour and social mechanism that exert male dominance. ${ }^{7}$ Here, two authors will be considered in particular. The first is Paul Lindau who uncritically pampered to the tastes of the public at that time for which he was rewarded by being extremely popular while the other is Richard Voß, an author who troubled the public with his view of justice and morality. Lindau came at the very beginning of the "Gründerzeit" period and to large extent symbolised it, while Voß wrote plays at the very end of this period and did not experience more significant public success. While Paul Lindau in his dramas extolled and idealised the world of "Gründerzeit", Voß showed the psychopathic state caused by the suppression of emotions and libido. Lindau's heroines therefore naturally fitted into an idealised bourgeois world and obediently accepted deserved rewards and deserved punishments even more while Voß's heroines did not accept the role of object and with the act of murder or suicide showed their rebellion against a hypocritical society.

\section{Paul Lindau}

Paul Lindau (1839-1919), journalist, literary critic and writer, was one of the most important dramatists of the "Gründerzeit". ${ }^{8}$ He was an exceptionally powerful person on

4 An analyses of the construction of female identity in the dramas by Paul Lindau nad Richard Voß see in: Grubišić Pulišelić, Eldi: Konstrukcija ženskog identiteta u njemačkoj drami. Tipizacija ženskih likova u kazališnom zrcalu 70-ih i 80-ih godina 19. stoljeća. Zagreb 2013.

5 See Bucher, Max: Realismus und Gründerzeit. Manifeste und Dokumente zur deutschen Literatur 18481880. II/1. Stuttgart 1976, pp. 149.

6 See Grubišić Pulišelić [ footnote 4], pp. 198.

7 In family dramas of the 18th and 19th century, fathers treated their daughters like property in the patriarchal spirit and they considered her honour as a guarantee for their own moral survival which resulted in girls who had sinned against civil feeling for morality, being sacrificed. See Sørensen, Bengt Algot: Herrschaft und Zärtlichkeit. Der Patriarchalismus und das Drama im 18. Jahrhundert. München 1984.

8 Kiefer [footnote 1], pp. 34-38. 
the cultural scene of his time and can be considered a symbol of his time. ${ }^{9}$ Today Lindau has almost been forgotten as a theatre writer and his place in German literature is mostly linked to film as a new medium at the beginning of the 20 th century. ${ }^{10}$ Marion is his first drama on social themes and emerged in 1869. The heroine at the beginning of the drama is a naive girl who follows social rules and accepts an arranged marriage, but due to external factors almost experiences a transformation of character and must face the consequences of double standards morality. Already at the first meeting her arranged fiancé mocks the concept of love and emphasizes the importance of respect in marriage which astonishes the young woman:

Die Liebe ist durchaus nicht ausgeschlossen, sie ist heutzutage nur nicht mehr obligatorisch. Es genügt für unsre moderne Ehe unter Umständen schon die Achtung. Eine tiefe ernste Achtung, die freilich von der Liebe so weit entfernt ist, wie der Kopf vom Herzen, die aber für das, was Sie, was wir alle in unsern heutigen Verbindungen vermissen, den höchsten und einzig möglichen Ersatz bietet. [...] Die Ehe ist also keine Quittung für Liebe, sondern eine Promesse auf Achtung. ${ }^{11}$

The concept of respect really represents the code for control of (above all female) libido limiting sexuality on the reproductive function by which patriarchal power is eventually ensured. ${ }^{12}$ Conflict occurs when lonely and unhappy Marion finds out that her husband is continuing to have an affair with an actress and in a pathetic monologue uncovers her resentment of double standards morality of a society which tolerates such behaviour:

Aha, Herr Graf, sie bilden sich ein, daß wir uns herbeilassen werden, Ihnen die Stunden zu verkürzen, in welchen jene-Damen anderweitig beschäftigt sind. Sie werfen Ihr Herz in den Staub und glauben, daß wir es dort aufnehmen werden? Sie glauben durch die Ehe ein Recht erlangt zu haben, sich aus den Armen Ihrer Courtisane in die Ihrer Gemahlin zu stürzen [...].13

However, even if understanding is shown for her rebellion against hypocritical social principles at the beginning, the writer at the end punished his heroine. Marion becomes an adulteress and by this act loses the right to her place in society. After her husband dies in a dual defending his wife's honour (although he was really defending his own

9 Berbig, Roland: Paul Lindau - eine Literatenkarriere. In: Wruck, Peter: Literarisches Leben in Berlin 1871-1933. Berlin 1987, pp. 88-125 (here p. 106).

10 See Eismann-Lichte, Anneliese: Paul Lindau. Publizist und Romancier der Gründerjahre. München 1981, pp. 111.

11 Lindau, Paul: Marion. Drama in vier Acten. In: Lindau, Paul: Theater, Volume 1. Berlin 1887, pp. 135-257 (here p. 12). Further references appear in the text with the abbreviation Lindau, Paul: Marion.

12 Döcker, Ulrike: Die Ordnung der bürgerlichen Welt. Frankfurt am Main 1994, pp. 229-230.

13 Lindau, Paul: Marion, pp. 46. 
honour), the young woman is forced to continue her existence in social isolation. ${ }^{14}$ After initial rebellion, Marion in a pathetic speech nevertheless demonstrates remorse for violating ethical rules: "Glauben Sie wirklich, daß ich in dieser Umgebung vergessen könnte, was ich verloren habe, was ich war und was ich bin." ${ }^{15}$ The heroine begins to behave particularly self-destructively, but before her death which is depicted as redemption for her sins, she meets the actress Amanda who in the past was her husband's lover. In admitting and accepting guilt and punishment, Marion again establishes harmony in the idealised world of "Gründerzeit". In a trivial and unconvincing shift the heroine calls herself a bad person and asks the man who was her lover and her husband's murderer for forgiveness: "Du hast mir noch viel zu vergeben, Alfred. Du hast mich treu geliebt, geliebt, als ich es nicht mehr verdiente! Ich war schlecht, Alfred. Vergibst Du mir? "16 As the consequence of the double standards of sexual morality in patriarchy, the woman was heavily punished while the man was exempted from wider social condemnation. Marion clearly says that her punishment was deserved and that the poverty in which she found herself was the consequence of her own sins: "Das Gewissen! Ja, wenn man noch einmal leben könnte, wenn man wüßte, wieviel Elend es gibt, und wie man für jeden Heller, den man verspielt, verpraßt und verschlemmt, Rechnung ablegen muß - man würde anders leben." ${ }^{17}$ After initial critical impulse, Lindau changes his attitude towards ingrained ethical values and in the unravelling of the drama satisfies the tastes of his conservative public. Marion is not a mythical heroine who succeeds in winning justice, but a woman whose rebellion against "Gründerzeit" ethics is punished by death.

Lindau's drama Maria und Magdalena in 1872 was viewed as being very successful, not only by the theatre public, but also by a huge number of theatre critics including Theodor Fontane. ${ }^{18}$ At the beginning of the drama, Lindau's powerful criticism dominated of typical representatives of a new social layer, the so-called "Parvenü", whose hypocritical feeling for honour and morality constituted a dominant social philosophy of life. ${ }^{19}$ Those belonging to "Parvenü" in all segments of life imitated aristocracy, and with their money they increasingly determined not only political, but also cultural life in the "Gründerzeit" period.$^{20}$ The drama's plot development is constructed on the fate of famous actress Maria Verrina who after many years of absence returns to her home

14 See Frevert, Ute: "Mann und Weib, und Weib und Mann. "Geschlechter-Differenzen in der Moderne. München 1995, pp. 217.

15 Lindau, Paul: Marion, pp. 72.

16 Lindau, Paul: Marion, pp. 95.

17 Lindau, Paul: Marion, pp. 88.

18 Fontane, Theodor: Kritische Jahre-Kritiker-Jahre. In: Schreinert, Kurt/Neuendorff-Fürstenau, Jutta: Von Zwanzig bis Dreißig. Autobiographisches. München 1967, pp. 387-406 (here p. 387).

19 Jost Hermand defines the new social elite: "Ein Parvenü ist [...] einer, der weder die Menschheit noch die eigene Klasse, sondern nur den eigene Aufstieg im Auge hat. Bei dem 'Citoyen' dankt man an [...] die Marseillaise, Fortschritt, zündende Konventsreden und heroische Brutusgesten; bei dem Wort 'Bourgeois' an gute Stube, Sparkassenbuch, [...]; bei dem Wort 'Parvenü' an Börsenspekulation, Ellbogendarwinismus, [...] und feudalistische Protzerei.” Hermand, Jost: Der gründerzeitliche Parvenü. In: Roters, Eberhard: Aspekte der Gründerzeit. Berlin 1974, pp. 7-14, (here p. 7).

20 Izenberg, Gerald: Die Aristokratisierung der bürgerlichen Kultur im 19. Jahrhunderts. In: Hohendahl, 
town. Maria must confront people who caused her great injustice in the past; her father threw her out of the family house after she had been accused for exchanging love letters with a teacher in the dormitory. Even though innocent, the young woman reported the punishment to protect her friend Magdalena. Maria's father Werren, in the drama depicted as a typical representative of "Parvenü", married Magdalena after his daughter's departure not knowing that it was actually her who wrote the love letters which caused events to erupt. Werren describes his main social ambition: "Freut mich also, daß Sie gekommen sind - neben den Spitzen des Adels wünsche ich auch die Kunst und die Gelehrtenwelt in meinen Salons vertreten zu sehen." ${ }^{21}$ In this drama, four significant levels related to "Gründerzeit" ethics could be analysed: the issue of exceptionally strict sexual morality for girls, marriage between older men and young women ${ }^{22}$, the social position of female actors and the issue of arranged marriage. Lindau shows how rigid sexual morality resulted in serious social disqualification of a girl, but criticism of it is mitigated by the fact that she was actually innocent:

Du kannst es Dir nicht vorstellen, Magdalena, was es heißt: seinem Vater gegenüber als bescholten dastehen. Einem Mädchen, das sich etwas vergiebt, vergeben andere nie! Und ich galt und gelte noch heute als ein verlorenes Mädchen. Der Himmel hat mich bewahrt, daß ich es nicht geworden bin.....Mit Schaudern denke ich daran, wie nahe mich Jammer und Noth dem Abgrund gebracht haben! Denn ich war hülflos, verlassen, in einem Lande, dessen Sprache ich nicht einmal verstand, das Geld ging zur Neige [...]. ${ }^{23}$

Similarly, in the issue of marriage between men and much younger women: the relationship between the father of the main heroine and her once best friend is not examined critically, but is rather shown as a social fact and does not become the subject of ethical uncertainty. The social position of female actresses is also depicted in a twisted and idealised light: Lindau depicted his heroine as a typical actress of her time who succeeded in saving her female virtue, which at the end of the drama will be rewarded by marriage to a duke. In contrast to Lindau's heroine, actresses were in reality the victims of financial and sexual abuse and often had the position of white slaves. ${ }^{24}$ In keeping with the idealised middle-class world in which she lived, Maria dreamt of leaving the acting scene and searching for happiness in marriage:

Peter Uwe [et al.]: Legitimationskrisen des deutschen Adels1200-1900. Stuttgart 1979, pp. 233-244, (here p. 233).

21 Lindau, Paul: Maria und Magdalena. Schauspiel in vier Acten. In: Lindau, Paul: Theater, Volume 1. Berlin 1887, pp. 135-257, (here p. 152). Further references appear in the text with the abbreviation Lindau, Paul: Maria und Magdalena.

22 See Schmid-Bortenschlager, Sigrid: Varianten und Variationen des Topos "Alter Mann-Junge Frau”. In: Klugsberger, Theresia [et al.]: Schwierige Verhältnisse. Liebe und Sexualität in der Frauenliteratur um 1900. Stuttgart 1992, pp. 5-18, (here p. 6).

23 Lindau, Paul: Maria und Magdalena, pp. 228.

24 McDonald, Jan: Die Schauspielerin - ein Beruf, der einer Frau nicht paßt. In: Möhrmann, Renate: Die Schauspielerin - Eine Kulturgeschichte. Frankfurt am Main and Leipzig 2000, pp. 197-234, (here p. 198). 
Ich wurde gefeiert, ich wurde beneidet - beneidet!! (Mit bitterm Lachen.) Ha! All meinen Ruhm, all den Flitterstaat und Plunder, der sich da aufgehäust hat, Alles, was ich erworben, mein Hab und Gut - ich gäb' es willig hin, wenn ich die eine Seite aus dem Buch meines Lebens, die Du kennst, herausreißen könnte! Meine Zukunft ist die Einsamkeit! Wem kann ich es zumuthen, sein Schicksal mit dem meinigen zu verbinden $[\ldots] . .^{25}$

Duke Bernd bravely decides to cancel an already arranged marriage with a princess and make the actress he loved his lawful wife instead of his mistress which was the common practice. ${ }^{26}$ He refuses to live like his predecessors and decides to marry for love: "Ich begreiffe! Wenn ich Prinzessin Eleonore ohne Liebe heirathe, sie und mich unglücklich mache, und Diejenige, die meinem Herzen vielleicht nahe steht, zu meiner Maitresse erniedrige - dann sind die Rücksichten, dann ist Stand und Anstand gewahrt?!"27 Lindau criticised arranged marriage which was characteristic at the time for aristocracy and propagated marriage for love as a new value of "Gründerzeit". The drama ends with a happy resolution of the conflicts: Maria forgives her father and marries duke Bernd. Causes and their consequences become irrelevant, as well as the question of guilt and innocence. The author in this way in great style celebrates the harmonisation of interpersonal relations and the victory of family ideologies over all trials of the new age.

\section{Richard Voß}

In the "Gründerzeit" period Richard Voß (1851-1918) was considered to be a famous writer whereas today he is almost completely forgotten. ${ }^{28}$ His drama Alexandra was staged for the first time in 1886, and it is interesting that Voß, compared to Lindau, has never been widely popular among the theatre public. His historical plays did not resound so significantly while the performances of his dramas such as Alexandra and Eva were received reservedly. Some literary theorists consider Voß to be the forerunner of German naturalism. ${ }^{29}$ However, his significance to German drama can be seen in that, despite trivial elements, he approached in another way the problem area of human sexuality, female and male honour, as well as the issue of social inter-relations, marriage and morality. His drama Alexandra represents a significant move in "Gründerzeit" theatre because he spoke about taboo topics; sexuality is not demonised and male honour is not idealised as in Lindau's dramas. The main character of the drama is Alexandra, a girl who has violated sexual morality and given birth to an illegitimate child. She was accused of infanticide which she had not committed and ended up in prison. The drama's plot

25 Lindau, Paul: Maria und Magdalena, pp. 228.

26 Möhrmann, Malte: Die Herren zahlen die Kostüme. Mädchen vom Theater am Rande der Prostitution. In: Möhrmann, Renate: Die Schauspielerin - Eine Kulturgeschichte. Frankfurt am Main and Leipzig 2000, pp. 292-317, (here p. 315).

27 Lindau, Paul: Maria und Magdalena, pp. 242.

28 Exept the novel "Zwei Menschen". See Kiefer [footnote 1], pp. 80-81.

29 Bernhardt, Rüdiger: Henrik Ibsen und die Deutschen. Berlin 1989, pp. 250. 
begins when seven years later, she has left prison and wants to take revenge upon Erwin, the man she blames for her unhappy situation. Voß examined and criticised the society who exclusively blame the woman for the violation of sexual morality so Alexandra talks of social hypocrisy and the discrimination of women by the law:

Aber, meine Herren Richter, da ihr nur für uns Betrogene Gesetze habt, nur für uns Rechtspruch und Strafe, so mögt ihr euch gefallen lassen, daß wir selbst unsre Sache führen. [...] Mit dem Recht, welches die Frauen zu fordern berechtigt, mit euch gleich zu sein vor dem Gesetz. Mit dem Recht, das dem Menschen gestattet, sich selbst Recht und Gerechtigkeit zu verschaffen, wird ihm beides verweigert. Wollen Sie, der Mann des Rechts, uns das verwehren? ${ }^{30}$

In the drama, two conflicts take place simultaneously: the first at an external level (the conflict between women and social morality) and the other at an internal level (the conflict between women and their own identity). Voß analysed the consequences of social repression on the life of the individual and in this segment of its creation talked of the subversive elements on the interpretation of social-political relations. ${ }^{31}$ Through interpersonal, but more so through internal conflicts of his heroes, the author criticised the disharmony of state legislation, social morality and human nature. Voß's reaching for trivial elements and justifications obvious above all in wondrous internal and external character transformations, cannot be denied. However, compared to his contemporaries, he insisted on acknowledging male guilt for the sin of extra-marital sexuality and considered male honour as a separate moral category. Whereas Lindau's Albert de Ribeau in Marion remained unpunished and was spared from not only social condemnation, but also from his own moral dilemmas, Erwin von Eberti in Voß's Alexandra was forced to take on his share of the responsibility. Albert at the end of the drama, like some sort of classical hero, utters the final words over the body of the dying female sinner. Seducers of innocent girls and married women mostly remained unpunished in "Gründerzeit" dramas, just as was usual in the 18th century bourgeois tragedies where they were tyrants above the law and the moral authority of society. ${ }^{32}$ In contrast, Voß's male characters have to confront the issue of their own morality and bear their share of the blame for the violation of sexual morality. Alexandra differs from clichéd female characters who abounded in drama productions at that time and she is not measured with double standards morality as the product of "Gründerzeit" ethics. The heroine has the strength to demand from her seducer to take her to his mother's house. Voß relativised female blame for extra-marital sexuality sins, but at the same time criticised the sexual stigma

30 Voß, Richard: Alexandra. Drama in vier Akten. In: Ausgewählte Werke, Vol. 4. Stuttgart 1922, pp. 6-78, (here p. 17). Further references appear in the text with the abbreviation Voß, Richard: Alexandra.

31 See Schanze, Helmut: Theater-Politik-Literatur. Zur Gründungskonstellation einer "Freien Bühne" zu Berlin 1889. In: Bayerdörfer, Hans Peter [et al.]: Literatur und Theater im Wilhelminischen Zeitalter. Tübingen 1978, pp. 282-287.

32 Lehmann, Christine: Das Modell Clarissa: Liebe, Verführung, Sexualität und Tod der Romanheldinnen des 18. und 19. Jahrhunderts. Stuttgart 1991, pp. 275-291, (here p. 141). 
in general. ${ }^{33}$ This is why in Alexandra we can talk about criticism which does not stop at individual behaviour, but spreads to government institutions and patriarchal society as a whole. Voß approached his main heroine as an individual and allowed her step into the typical male world of examining moral responsibility. So she criticises hypercritical relations between society and sexuality: "Schwach nennen Sie uns? Wir sind es! Aber wer versteht mit meisterlicher Kunst, unsere Schwäche zu einem Verbrechen zu machen? Und dann, dann jede Entschuldigung dem Verführer, jede Schuld der Verführten!"34 The heroine speaks out about the injustices regarding women and demonstrates willingness for sacrifice in the battle for civil rights: "Wir verderben zu Hunderten, zu Tausenden, jeden Tag, jede Stunde, ohne daß es einen von euch kümmert. Im Namen jener Hunderten und Tausenden von Verdorbenen will ich mir zu meinem Recht verhelfen und sollte ich darüber vollends zugrunde gehen." ${ }^{55}$ Not knowing that she has spent the last seven years in prison for infanticide, Erwin agrees to take Alexandra to the home of his mother and in the drama a certain parallel reality is created founded on trivial and pathetic elements. They fall in love again and future is shown for a moment as an independent category. The lovers believe that the past can be erased: "Was kümmert es uns, daß wir einmal waren? Wir sind, wir werden sein! Gegenwart und Zukunft sind unsere Götter. Die Vergangenheit ist ein Grab, wir aber sind im Licht der Sonne geblieben." 36 In this parallel world all roles are redefined and love is portrayed as dominant ideal. Already in the following scene Voß leads the plot into a much more realistic direction and Erwin's mother finds out the truth about Alexandra's past and asks her to leave her son forever. Alexandra tries to justify herself to no avail:

Halb von Sinnen vor Jammer gebar's ich. [...] Da lag es in meinem Schoß, ein zartes, schwaches Geschöpf, kaum sich regend, kaum atmend. [...] Und ich konnte es nicht bewahren vor dem Furchtbaren, konnte mein Kind nicht retten, mit meiner ganzen gewaltigen Mutterliebe konnt' ich das nicht. Und da lag es und sah mich an, ernst, wie vorwurfsvoll, wie fürchterlich fragend: warum hast du mir das Leben gegeben? ${ }^{37}$

Alexandra comprehends that she will never escape her past and with the act of suicide confirms the painful absurdity of her position. Erwin's mother supports her decision: "Der Herr segne und behüte dich; der Herr lasse sein Anlitz leuchten über dir und gebe dir seinen Frieden." ${ }^{8}$ Alexandra places a marriage wreath on her head, drinks the poison and dies while listening to children's voices singing Christmas songs: "Kinder singen mich in Schlaf. Von Kinderlippen wird mir die Verkündigung gegeben. Du bist

33 See Catani, Stephanie: Das fiktive Geschlecht. Weiblichkeit in anthropologischen Entwürfen und literarischen Texten zwischen 1885 und 1925. Würzburg 2005, pp. 53.

34 Voß, Richard: Alexandra, pp. 17.

35 Voß, Richard: Alexandra, pp. 18.

36 Voß, Richard: Alexandra, pp. 53.

37 Voß, Richard: Alexandra, pp. 70.

38 Voß, Richard: Alexandra, pp. 76. 
barmherzig, Gott." ${ }^{9}$ Voß again escapes to triviality and makes Alexandra into a tragic heroine, but opposed to Lindau's Marion, his heroine does not die because she accepts her blame, but because she is conscious that she cannot fight against the mechanisms of social repression. She is forever marked as an "unnatural mother" in a male world of law and justice and she is forced to bear alone the punishment for extra-marital love:

Ein Kind wird geboren. Zuweilen soll es vorkommen, daß eine solche Mutter ein Verbrechen begeht, einen - Mord. Sie wird angeklagt, sie wird gerichtet, nach dem Gesetz, das für solche ,unnatürliche Mütter', wie man es nennt, von weisen und gerechten Männern eingesetzt worden. Eine solche Mutter verfällt dem Gesetz, aber der Vater ... Für den Vater gibt es kein Gesetz, keine Vergeltung. ${ }^{40}$

Voß's heroine is not just a passive observer manipulated in a dominant male world, she is an active participant of life making decisions about her own fate. Her identity is no longer relative as in the heroine of family tragedies in the 18th century who exists just to support the development of the male identity. ${ }^{41}$ Furthermore, while in most literary works on the theme of seduction, the heroines die in order to show acceptance of guilt for the sins of extra-marital sexuality and deserve forgiveness, ${ }^{42}$ Alexandra's suicide is an act of rebellion and marks the beginning of a social metamorphosis.

Voß's countess Eva from the eponymous drama belongs to the aristocracy. Her life changes completely firstly when she is left without her father and the safety of her own home; later she becomes an adulteress and is cast off from society. In keeping with "Gründerzeit" ethics, her father committed suicide after the stock crash and bankruptcy into which he pulled other families. Her fiancé Elimar leaves her financially ruined and socially resented and she ceases to be the unattainable ideal woman for the craftsman Hartwig who offers her marriage as a way out of her difficult situation. Eva accepts the marriage, but will never completely live again under new social circumstances and compares herself to a bird in a cage: "Armer Gefangener! Sitzest im Käfig und singst. Ich bin längst stille geworden." ${ }^{43}$ When her former fiancé suddenly returns and offers her an escape from the small-minded daily routine and a return to the world where she belonged, an internal conflict arises within the heroine. ${ }^{44}$ Aware of the fact that a child born in marriage belongs to the father and that leaving the husband's house implies giv-

39 Voß, Richard: Alexandra, pp. 78.

40 Voß, Richard: Alexandra, pp. 41.

41 Beyer, Karen: "Schön wie ein Gott und männlich wie ein Held." Zur Rolle des weiblichen Geschlechtscharakters für die Konstituierung des männlichen Aufklärungshelden in den frühen Dramen Schillers. Stuttgart 1993, pp. 331.

42 Lehmann [footnote 32], pp. 141.

43 Voß, Richard: Eva. Schauspiel in fünf Akten. In: Ausgewählte Werke, Vol. 4. Stuttgart 1922, pp. 79-162 (here p. 110). Further references appear in the text with the abbreviation Voß, Richard: Eva.

44 See Wesel, Uwe: Der Mythos vom Matriarchat. Über Bachofens Mutterrecht und die Stellung von Frauen in frühen Gesellschaften vor der Erstehung staatlicher Herrschaft. Frankfurt a. M. 1980, pp. 16. 
ing up motherhood, ${ }^{45}$ Eva at first in front of her former fiancé defends her new life: "Ich bin das Weib eines vortrefflichen Mannes, den ich achte und zu dem ich emporblicke; ich habe ein holdes Kind; ich erfülle eine schöne Pflicht, wenigstens trachte ich danach, sie zu erfüllen. Mein Mann ist glücklich." ${ }^{46}$

The truth that Eva tells about her marriage turns into a painful truth for all women in loveless marriages:

Niemand sah die Wunden, die ich meinem Herzen schlug - auch du nicht, der sie hätte sehen müssen; niemand gewahrte, wie ich langsam, qualvoll umkam - auch du nicht, vor dessen Augen es geschah. Zuerst war's gewesen, als wäre eine Gottheit zu dir niedergestiegen; doch es dauerte nicht lange, da war ich auch für dich nur ein Weib: dein Weib, von dem du alles fordern konntest, was ein Mann von seinem Weibe zu fordern berechtigt ist. ${ }^{47}$

Eva in this way sets herself up as a representative for all women and mothers whose subservient role in the family and society is clearly implied. ${ }^{48}$ The moment when she gives up her loveless marriage, she is also forced to give up her own child: "Dein Weib kann ich doch nicht länger sein; wie könnte ich da die Mutter deines Kindes bleiben?" 49 Eva publicly declares herself as an adulteress when she leaves her lawful husband and continues life in a common law marriage. Elimar will not give her the love she was searching for and despite her sacrifice will continue to live in debauchery. Without suspecting that her love has already found a new subject of his sexual desires, Eva looks forward to the divorce which would legalise her relationship with Elimar. Toinette, one of the girls that Elimar seduced and then left, arrives at her door and the main heroine must face the truth about his character. When Eva confronts him with evidence about his immorality and unscrupulous behaviour, he defends himself with the inviolability of his male position and lays all the blame on the woman: "Sie war nicht viel wert, leichtsinnig und genußsüchtig. [...] Unmöglich kann man für die Leichtfertigkeit eines Weibes den Mann zur Verantwortung ziehen. [...] Wir können eure Tugend nicht schützen." ${ }_{50}$ Realising that she herself has become a victim, Eva like her fictional sister Alexandra speaks out about the double standards morality of society as well as about the gross injustice which has for centuries been done to women:

Aber ihr könnt heucheln und lügen, Meineide schwören und Herzen vergiften, ihr könnt eure Künste so lange spielen lassen, bis ihr unsere Tugend zu Fall gebracht habt. Und wenn es euch dann gelungen ist, wenn ihr dem Bräutigam die Braut, dem Gatten die Gattin, dem Kinde

45 See Weiland, Daniela: Geschichte der Frauenemanzipation in Deutschland und Österreich. Düsseldorf 1983, pp. 225-226.

46 Voß, Richard: Eva, pp. 115.

47 Voß, Richard: Eva, pp. 128.

48 See Duden, Barbara: Das schöne Eigentum. Zur Herausbildung des bürgerlichen Frauenbildes an der Wende vom 18. zum 19. Jahrhundert. In: Kursbuch, 47 (1977), pp. 125-140 , (here p. 134).

49 Voß, Richard: Eva, pp. 129.

50 Voß, Richard: Eva, pp. 148. 
die Mutter nahmt, aus Reinen-Gefallene, aus ehrlichen Frauen - Dirnen machtet, dann alle Schuld auf uns, alle, alle Schuld auf uns..$^{51}$

Eva accepts her guilt for the adultery, but wants to save her child's honour seeking from her lover to protect her with marriage:

Denn die Frau, die den Namen jenes Ehrenhaften geführt hat, darf von der Welt nicht mit Schande bedeckt dastehen; das Kind, das ich diesem Manne geboren habe, darf nicht eine Mutter besitzen, die keine ehrliche Frau mehr ist. Mag dann aus mir werden, was will - vorher verlange ich von dir, mir mein Recht zu geben. [ ...] Erhebe die Hand und schwöre, dass du mich zu deinem Weibe machen willst [ ...]. Du und deinesgleichen, ihr jagt uns in Schande und Tod; du und deinesgleichen, ihr lebt weiter, mordet weiter. Und es gibt für euresgleichen kein Gericht, keinen Ankläger, keinen Urteilsspruch. Erhebe die Hand und schwöre, oder ich schaffe mir selbst mein Recht, das Recht der Wiedervergeltung. ${ }^{52}$

When Elimar refuses to offer her the moral satisfaction of marriage, she takes justice into her own hands and kills him by shooting him with Toinette's gun, by which she takes on a typically male form of behaviour and takes revenge for her lost honour. Instead of waiting for resolution of the conflict from the outside world, Eva, aware of social mechanisms, herself condemns her seducer to the punishment of death. Female honour in this way is emancipated and is no longer male property. ${ }^{53}$ In the last act of the drama partial harmonisation is achieved. Eva spends her last days as a seriously ill prisoner, completely aware that nothing can erase her guilt:

Ich bin keine Märtyrerin und will keine sein. Niemals habe ich mit mir selber Erbarmen gefühlt. Ich beklage mich nicht, weder über die Strenge des Gesetzes noch über das Urteil der Richter. Man hat mir ja Milderungsgründe zuerkannt. Und ich verdiene Strafe. - Denn ich nahm die Vergeltung, die ich einem anderen, höheren Richter hätte überlassen sollen, selbst in meine Hände. [ ... ] In den langen, langen Jahren bleibe ich, was ich gewesen bin! Die Zuchthäuslerin, die Mörderin, die pflichtvergessene Gattin und Mutter. Die Sühne ist geschehen, aber die Schuld bleibt. ${ }^{54}$

Voß's heroine is in no way a stereotypical woman who quietly accepts the role of victim in society; by the act of murder Eva publicly announces her rebellion showing courage, but at the same time oversteps the boundary between sympathy of the theatre audience and their condemnation. In order by her fate to encourage contemplation and influence

51 Voß, Richard: Eva, pp. 149.

52 Voß, Richard: Eva, pp. 151.

53 In opposition to the concept of honour in tragedies of the 18th century. See Lee, Kyeonghi: Weiblichkeitskonzeptionen und Frauengestalten im theoretischen und literarischen Werk Friedrich Schillers. Univ. Diss., Marburg 2003, pp. 151, online: https://www.deutsche-digitale-bibliothek.de/binary/6I7PG5SJYW3RGIEMI6FSITTEANERGTTW/full/1.pdf (accessed 22 November 2016)

54 Voß, Richard: Eva, pp. 155. 
change, the heroine must be partially accepted by the theatre audience so Eva will repent for multiple violations of the ethical code of the society. The author obviously is looking for a way to re-establish the balance in the world of "Gründerzeit" and the end of the drama offers trivial conflict resolution. The heroine at her death makes peace with the people who directly or indirectly contributed to her tragedy. In the pathetic scene in which Eva kneels by her husband the taste of the theatre audience is obvious, who in her open repentance saw victory of ethics and justice. The abandoned and shamed husband appears in the hospital infirmary and forgives her adultery in the Christian spirit and is even willing to take her back:

Ich nehme dich mit mir, wir gehen fort, ich und du, die Mutter und das Kind. Wir sind alle wieder beisammen, wir denken an keine Vergangenheit, wir sind glücklich! Du erholst dich, $\mathrm{du}$ wirst wieder gesund, blühend und froh. Wir leben in einem anderen Lande, vergessen und verschollen..$^{55}$

Furthermore, while in the socio-historical context of "Gründerzeit" female adultery was not only considered as an unforgiveable offence, but also as a crime ${ }^{56}$ the author through the character of Hartwig elevated himself above that stereotypical way of thinking. Eva accepts the forgiveness of her surroundings, but also forgives herself by which the strict ethical principles of "Gründerzeit" are actually relativised:

So ist es also doch wahr, dass einem Sünder vergeben, dass eine Schuld gesühnt werden kann? Und das schon hier auf Erden! Es ist zu viel des Glücks. Vielleicht sollte ich es mir nicht gönnen, aber mir fehlen zum Widerstand die Kräfte, und ich bin ja auch ein Geschöpf, das nach Glück durstet und dem es graust vor dem Verschmachten. [ ... ] Vater im Himmel, deine Wege führen wunderbar! $!^{57}$

Her death is not only the reflection of the "Clarissa model" 58 as is the case with Lindau because Voß's heroine dies after she punishes the man who did not only bring her unhappiness, but many other women as well. Elimar will not remain unpunished like most seducers at the time and the author will, through the character of one brave woman, send a message about the causes and consequences of social repression.

\section{Conclusion}

German dramatists of "Gründerzeit" tended to promote bourgeois values, but some authors critically spoke about the ethical standards of the new social elite. In this article

55 Voß, Richard: Eva, pp. 160.

56 See Frevert [footnote 14], pp. 183.

57 Voß, Richard: Eva, pp. 161.

58 See Lehmann [footnote 32], pp. 10. 
I considered the work of two authors; the extremely popular Paul Lindau and the less popular Richard Voß. I have showed that Lindau's heroines fitted into an idealised bourgeois world of high ethical values while Voß's heroines were rebels against a double standard morality. The heroine from Lindau's drama Marion is a naive girl who follows social rules and accepts an arranged marriage, but she becomes an adulteress and is forced to continue her existence in social isolation. After initial critical impulse, Lindau changes his attitude towards Marion and punishes her by death. In the drama Maria und Magdalena Lindau criticizes the so-called "Parvenü", the typical representative of the new social elite which imitated aristocracy in many segments of life. Lindau shows how a double moral standard results in social disqualification of a young woman, but idealises the bourgeois values as woman's virtue and rectitude. The drama ends with a happy resolution of all the conflicts; the question of guilt and innocence becomes irrelevant as the victory of family ideology is celebrated. In comparison to Paul Lindau, Richard Voß has never been widely popular among the theatre audience. In his drama Alexandra he does not only speak about a double standard morality, but also about taboo topics as female sexuality and infanticide. He analysed the consequences of social repression on the life of a single woman and his interpretation of social-political relations is very subversive. Whereas Lindau's seducer Albert de Ribeau in Marion remained unpunished, Erwin von Eberti in Voß's Alexandra was forced to take his part of guilt and responsibility. Alexandra differs from clichéd female characters who abounded in drama productions at that time and she criticises hypercritical relations between society and ethical values. Opposed to Lindau's Marion, Alexandra does not die because she accepts her blame, but because she is conscious forever marked in a world of male law and justice. Voß's Eva from the of being eponymous drama becomes an adulteress because she lives in a loveless marriage. Like her fictional sister Alexandra, Eva speaks out about an ethical double standard of society. She accepts her guilt for the adultery, but wants to save her child's honour. Realising that she herself and her daughter have become victims of an immoral man, she takes justice into her own hands. Voß's heroines are not stereotypical women who quietly accept the role of a victim: By the act of suicide and murder, Eva and Alexandra show rebellion and courage, but at the same time overstep the boundary between sympathy of the theatre audience and their indignation. While Lindau was idealising the bourgeois worldview and way of life, Voß criticised disharmony of state legislation, social ethics and human nature. The dramas by Paul Lindau and Richard Voß can be viewed in the light of the political discourse which was presented in theatre; "Gründerzeit" ethics in them show their front and flip side, power and weakness, hypocrisy and social conditioning.

\section{Bibliography}

BERBIG, Roland (1987): Paul Lindau - eine Literatenkarriere. In: Wruck, Peter: Literarisches Leben in Berlin 1871-1933. Berlin, pp. 88-125.

BERNHARDT, Rüdiger (1989): Henrik Ibsen und die Deutschen. Berlin. 
BEYER, Karen (1993): "Schön wie ein Gott und männlich wie ein Held.” Zur Rolle des weiblichen Geschlechtscharakters für die Konstituierung des männlichen Aufklärungshelden in den frühen Dramen Schillers. Stuttgart.

BUCHER, Max (1976): Realismus und Gründerzeit. Manifeste und Dokumente zur deutschen Literatur 1848-1880. Stuttgart 1976.

CATANI, Stephanie (2005): Das fiktive Geschlecht. Weiblichkeit in anthropologischen Entwürfen und literarischen Texten zwischen 1885 und 1925. Würzburg.

DÖCKER, Ulrike (1994): Die Ordnung der bürgerlichen Welt. Frankfurt am Main.

DUDEN, Barbara (1977): Das schöne Eigentum. Zur Herausbildung des bürgerlichen Frauenbildes an der Wende vom 18. zum 19. Jahrhundert. In: Kursbuch, 47, pp. 125-140.

EISMANN- LICHTE, Anneliese (1981): Paul Lindau. Publizist und Romancier der Gründerjahre. München.

FONTANE, Theodor (1967): Kritische Jahre-Kritiker-Jahre. In: Schreinert, Kurt/NeuendorffFürstenau, Jutta: Von Zwanzig bis Dreißig. Autobiographisches. München, pp. 387-406.

FREVERT, Ute (1995): "Mann und Weib, und Weib und Mann. "Geschlechter-Differenzen in der Moderne. München.

GRUBIŠIĆ PULIŠELIĆ, Eldi (2013): Konstrukcija ženskog identiteta u njemačkoj drami. Tipizacija ženskih likova u kazališnom zrcalu 70-ih i 80-ih godina 19. stoljeća. Zagreb 2013.

HAMANN Richard - HERMAND, Jost (1974): Gründerzeit. Epochen deutscher Kultur von 1870 bis zur Gegenwart. München.

KIEFER, Sascha (1998): Dramatik der Gründerzeit. Deutsches Drama und Theater 1870-1890. St. Ingbert.

LINDAU, Paul (1887): Maria und Magdalena. Schauspiel in vier Acten. In: Lindau, Paul: Theater, Volume 1. Berlin, pp. 135-257.

LINDAU, Paul (1887): Marion. Drama in vier Acten. In: Lindau, Paul: Theater, Volume 1. Berlin, pp. $135-257$.

HERMAND, Jost (1974): Der gründerzeitliche Parvenü. In: Roters, Eberhard: Aspekte der Gründerzeit. Berlin, pp. 7-14.

IZENBERG, Gerald (1979): Die Aristokratisierung der bürgerlichen Kultur im 19. Jahrhunderts. In: Hohendahl, Peter Uwe [et al.]: Legitimationskrisen des deutschen Adels 1200-1900. Stuttgart, pp. 233-244.

LEE, Kyeonghi (2003): Weiblichkeitskonzeptionen und Frauengestalten im theoretischen und literarischen Werk Friedrich Schillers. Univ. Diss., Marburg 2003, pp. 151, online: https://www. deutsche-digitale-bibliothek.de/binary/6I7PG5SJYW3RGIEMI6FSITTEANERGTTW/full/1. pdf (accessed 22 November 2016)

LEHMANN, Christine (1991): Das Modell Clarissa: Liebe, Verführung, Sexualität und Tod der Romanheldinnen des 18. und 19. Jahrhunderts. Stuttgart.

MCDONALD, Jan (2000): Die Schauspielerin-ein Beruf, der einer Frau nicht paßt. In: Möhrmann, Renate: Die Schauspielerin-Eine Kulturgeschichte. Frankfurt am Main and Leipzig, pp. 197-234.

MC INNES, Edward (1996): Drama und Theater. In: Mc Innes, Edward/ Plumpe, Gerhard: Bürgerlicher Realismus und Gründerzeit 1848-1890. München, pp. 343-393.

MÖHRMANN, Malte (2000): Die Herren zahlen die Kostüme. Mädchen vom Theater am Rande der Prostitution. In: Möhrmann, Renate: Die Schauspielerin - Eine Kulturgeschichte. Frankfurt am Main and Leipzig, pp. 292-317.

SCHANZE, Helmut (1978): Theater - Politik - Literatur. Zur Gründungskonstellation einer "Freien Bühne" zu Berlin 1889. In: Bayerdörfer , Hans Peter [et al.]: Literatur und Theater im Wilhelminischen Zeitalter. Tübingen, pp. 275-291. 
SCHMID-BORTENSCHLAGER, Sigrid (1992): Varianten und Variationen des Topos "Alter Mann - Junge Frau”. In: Klugsberger, Theresia [et al.]: Schwierige Verhältnisse. Liebe und Sexualität in der Frauenliteratur um 1900. Stuttgart, pp. 5-18.

SØRENSEN, Bengt Algot (1984): Herschaft und Zärtlichkeit. Der Patriarchalismus und das Drama im 18. Jahrhundert. München.

VOSS, Richard (1922): Alexandra. Drama in vier Akten. In: Ausgewählte Werke, Vol. 4. Stuttgart 1922, pp. 6-78.

VOSS, Richard (1922): Eva. Schauspiel in fünf Akten. In: Ausgewählte Werke, Vol. 4. Stuttgart 1922, pp. 79-162.

WEILAND, Daniela (1983): Geschichte der Frauenemanzipation in Deutschland und Österreich. Düsseldorf.

Ao. Univ. Prof. Dr. Eldi Grubišić Pulišelić / eldi@pmfst.hr

Universität Split, Philosophische Fakultät,

Zagrebačka 21, 21000 Split, Kroatien 